\title{
AVAILABLE AGRICULTURAL AREAS AND OWNERSHIP STRUCTURE OF HOLDINGS IN THE REPUBLIC OF SERBIA
}

\author{
Nada Trivić ${ }^{1}$ \\ *Corresponding author E-mail: nada.trivic@ef.uns.ac.rs
}

\begin{abstract}
A R T I C LE IN F O
A B S T R A C T

Original Article

Received: 02 December 2020

Accepted: 31 May 2021

doi:10.5937/ekoPolj2102291T

UDC 332.62:347.721(497.11)

The subject of research in this paper is the analysis and presentation of data on agricultural holdings, the structure of available and utilized area. The main goal is to determine and explain more comprehensively and in detail, by using appropriate methods, and based on available data, the condition of utilized agricultural area and its characteristics

Keywords: by utilization categories and ownership structure of holdings. The importance of this research arises from the fact that the results on utilized agricultural area can utilized/unutilized agricultural area, agricultural holdings, ownership structure

JEL: Q15, Q24, R14 be used to adopt appropriate measures and undertake certain activities in land and overall agricultural and rural policy related to sustainable utilization, arrangement and protection of agricultural land and more balanced integrated development of rural areas, as well as to find better solutions in the field of utilization, ownership sector and conditions of agricultural area management.
\end{abstract}

(C) 2021 EA. All rights reserved.

\section{Introduction}

Starting from the fact that the data on the structure of the agricultural holdings play a key role in implementation and monitoring the agricultural policy of the European Union (EU), The Statistical Office of the Republic of Serbia (hereinafter: the Office) planned, organized and conducted the "Agricultural farms structure survey (hereinafter: the Survey) in 2018" The survey was conducted on a sample that included 121,070 agricultural holdings. It was funded from the budget of the Republic of Serbia and from the pre-accession funds of the European Union, within the IPA 2016 project (Instrument for Pre-accession Assistance, 2016). The survey is a nationally significant, organizationally and programmatically very comprehensive activity of the Office in the field of agriculture. The obtained data will serve for the creation of the national agrarian policy, and for providing the basis for the functioning of the system of agricultural statistics. Applied instruments, coverage, features and standardization of concepts and definitions are in line with the recommendations of the World Programme for the census of Agriculture (UN-FAO), the European Parliament Regulations on conducting

1 Nada Trivić, Ph.D., Full Professor, Department of International Economics and Business, University of Novi Sad, Faculty of Economics in Subotica, 24000 Subotica, Segedinski put 9-11, Serbia, E-mail: nada.trivic@ef.uns.ac.rs 
the Farm Structure Survey and Survey on Agricultural Production Method (Regulation [EC] No 1166/2008 of the European Parliament and of the Council of 19. November 2008, on farm structure surveys and survey on agricultural production methods; Regulation [EC] No 1200/2009, Regulation [EU] No 715/2014), Eurostat methodology and valid domestic regulations. Besides the agricultural census, the Survey is a key research that collects internationally comparable data on the funds and structure of agricultural holdings.

An important segment of the analysis of the collected data is the analysis of available agricultural land by categories of utilization and the ownership structure of holdings in the Republic of Serbia, in 2018. The results of such an analysis are intended for the wider scientific and professional public, with the desire to expand agro-economic and statistical analysis of the utilization, arrangement and protection of agricultural land in Serbia - especially by municipalities and areas (Đorđević, at al 2011). The presented results can be significant indicators by which the state and local government will be able to define the problems of agricultural activity more adequately and accordingly plan and make appropriate decisions and take appropriate measures for development, both at the local and state level (Petrović, Miladinović, Novakov, 2007) .

\section{Materials, methods, goals and significance of the research}

The subject of research in this paper is the analysis and presentation of data on agricultural holdings, the structure of available and utilized area. Main goal of this research is to determine and explain more comprehensively and in detail, and based on available databases, professional literature and legislation, using appropriate methods, the condition of utilized agricultural area (hereinafter: UAA) and its quantitative and qualitative characteristics - in total and by types of agricultural holdings (hereinafter: AHs) - family agricultural holdings (FAHs) and agricultural holdings of legal entities and entrepreneurs (AHLEEs), by statistical regions and lower statistical units of data grouping (districts and municipalities). The justification of such a defined goals stems from the knowledge that the current tendencies and the current situation in the management of agricultural area in general, and especially arable land and areas under orchards and vineyards (Todić, 2019), as production-significant utilization categories of agricultural area, are considered sporadically, without critical consideration of responsibility of their owners and/or users.

Implementation of such a defined basic research goal indicates necessity of more detailed and continuous study of the causes that led to the reduction of available agricultural land and especially its better and more important production categories of utilization (Tomić, Njegovan, 2013).

The importance of this analysis stems from the possibility to point out to the scientific and professional public, competent state institutions, owners and/or users of agricultural area, the need to utilize, arrange and protect agricultural area in Serbia in accordance with the principle of sustainability (Trivić, 2019). 
The significance of this research stems from the fact that the results of the analysis of utilized agricultural area can be used to adopt appropriate measures and undertake certain activities in land and overall agricultural and rural policy (Bogdanov, 2007) related to sustainable use, arrangement and protection of agricultural area and more even integrated development of rural areas (European Commission, 2012), as well as to find better solutions in the field of utilization, ownership sector and conditions of agricultural land management.

\section{Results}

The starting point and backbone of all the observed parameters is precisely the structure of agricultural holdings AHs in Serbia. The results show that there were a total of 564,542 AHs in Serbia in 2018, of which 562,895 were family agricultural holdings (FAHs), only 1,375 agricultural holdings of legal entities (AHLEs) and 272 agricultural holdings of entrepreneurs (AHEs). It can be concluded that the total number of agricultural holdings is dominated by FAHs (99.71\%).

Table 1. Basic indicators on the number and size of AH in the Republic of Serbia, 2018

\begin{tabular}{|l|r|r|r|r|r|r|r|}
\hline \multirow{2}{*}{ Holdings } & \multicolumn{2}{|c|}{ All AHs } & \multicolumn{2}{c|}{ AHs without land } & \multicolumn{3}{c|}{ UAA } \\
\cline { 2 - 8 } & number & $\%$ & number & $\sum=100$ & ha & $\%$ & ha/AH \\
\hline FAH & 562895 & 99.71 & 5180 & 97.92 & 2916125 & 83.90 & 5.18 \\
\hline AHLE & 1375 & 0.24 & 70 & 1.32 & 557866 & 16.05 & 405.72 \\
\hline AHE & 272 & 0.05 & 40 & 0.76 & 1903 & 0.05 & 7.00 \\
\hline All AHs & 564542 & 100.00 & 5290 & 100.00 & 3475894 & 100.00 & 6.16 \\
\hline
\end{tabular}

Source: author's calculation based on data of the Statistical Office of the Republic of Serbia

AHLEEs are minor in number (only $0.24 \%$ and $0.05 \%$ ), but this group has a significant share in UAA and a large average area of property, so it can be concluded that they are significant production and economic entities in Serbian agriculture. However, at the same time, their participation in the NUAA is relatively large.

Table 2. Agricultural holdings with the status of legal entity, by regions

\begin{tabular}{|l|r|r|r|r|r|r|r|}
\hline \multirow{2}{*}{} & \multicolumn{9}{|c|}{ AHs } \\
\cline { 2 - 8 } & \multirow{2}{*}{$\begin{array}{c}\text { number of } \\
\text { holdings }\end{array}$} & \multicolumn{2}{|c|}{ FAHs } & \multicolumn{4}{|c|}{ AHLEEs } \\
\cline { 3 - 9 } & & number & $\%$ & number & $\%$ & number & $\%$ \\
\hline REPUBLIC OF SERBIA & 564542 & 562895 & 100.00 & 1375 & 100.00 & 272 & 100.00 \\
\hline SERBIA - NORTH & 157104 & 156138 & 27.74 & 855 & 62.18 & 111 & 40.81 \\
\hline Belgrade Region & 30033 & 29949 & 5.32 & 75 & 5.45 & 9 & 3.31 \\
\hline Vojvodina Region & 127071 & 126189 & 22.42 & 780 & 56.73 & 102 & 37.50 \\
\hline SERBIA-SOUTH & 407438 & 406757 & 72.26 & 520 & 37.82 & 161 & 59.19 \\
\hline $\begin{array}{l}\text { Sumadija and West } \\
\text { Serbia Region }\end{array}$ & 242636 & 242224 & 43.03 & 300 & 21.82 & 112 & 41.18 \\
\hline $\begin{array}{l}\text { South and East Serbia } \\
\text { Region }\end{array}$ & 164802 & 164533 & 29.23 & 220 & 16.00 & 49 & 18.01 \\
\hline Kosovo Region & $\ldots$ & $\ldots$ & $\ldots$ & $\ldots$ & $\ldots$ & $\ldots$ & $\ldots$ \\
\hline
\end{tabular}

Source: author's calculation based on data of the Statistical Office of the Republic of Serbia

http://ea.bg.ac.rs 
Regionally, the largest number of FAHs is in the region of Šumadija and Western Serbia $(42.97 \%)$. This region has the largest number of agricultural holdings of entrepreneurs AHEs (41.2\%), while the largest number of AHLEs is in the Region of Vojvodina (56.0\%).

Table 3. Available land per utilization categories in the Republic of Serbia, 2018.

\begin{tabular}{|c|c|c|c|c|c|c|}
\hline & \multicolumn{6}{|c|}{$\mathbf{A L}$} \\
\hline & \multirow{2}{*}{ total } & \multicolumn{3}{|c|}{ agricultural land } & \multirow{2}{*}{$\begin{array}{r}\text { Woodland } \\
\text { area }\end{array}$} & \multirow{2}{*}{ other } \\
\hline & & all & UAA & NUAA & & \\
\hline Area [ha] & 5178692 & 3765847 & 3475894 & 289953 & 972283 & 440562 \\
\hline Structure $[\%]$ & 100.00 & 72.72 & 67.12 & 5.60 & 18.77 & 8.51 \\
\hline
\end{tabular}

Source: author's calculation based on data of the Statistical Office of the Republic of Serbia

The structure of available land per utilization categories in Serbia is strongly dominated by UAA $(67.12 \%)$ - which makes a total of $72.2 \%$ of available agricultural land together with NUAA (5.60\%). It is followed by woodland (18.77\%) and other land (8.51\%) (Table $3)$. If we take into account the significant differences in the categories of available land by region, it is desirable to look at this structure of the UAA and NUAA and by districts.

Table 4. Available land per districts in the Republic of Serbia, 2018.

\begin{tabular}{|c|c|c|c|c|c|c|c|c|c|}
\hline & \multicolumn{2}{|c|}{ UAA } & \multicolumn{2}{|c|}{ NUAA } & \multicolumn{2}{|c|}{$\begin{array}{c}\text { Woodland } \\
\text { area }\end{array}$} & \multicolumn{2}{|c|}{ Other land } & \multirow{2}{*}{\begin{tabular}{|c|}
$\begin{array}{c}\text { AL } \\
\text { total }\end{array}$ \\
ha
\end{tabular}} \\
\hline & ha & $\%$ & ha & $\%$ & ha & $\%$ & ha & $\%$ & \\
\hline REPUBLIC OF SERBIA & $\begin{array}{r}3475 \\
894\end{array}$ & 67.12 & $\begin{array}{l}289 \\
953\end{array}$ & 5.60 & $\begin{array}{l}972 \\
283\end{array}$ & 18.77 & $\begin{array}{l}440 \\
562\end{array}$ & 8.51 & $\begin{array}{r}5178 \\
692\end{array}$ \\
\hline SERBIA - NORTH & $\begin{array}{r}1719 \\
899 \\
\end{array}$ & 76.56 & $\begin{array}{r}76 \\
982 \\
9\end{array}$ & 3.43 & $\begin{array}{l}158 \\
199\end{array}$ & 7.04 & $\begin{array}{l}291 \\
414 \\
\end{array}$ & 12.97 & $\begin{array}{r}2246 \\
494 \\
\end{array}$ \\
\hline Belgrade Region & 145533 & 55.26 & $\begin{array}{r}12 \\
340\end{array}$ & 4.69 & $\begin{array}{r}30 \\
648\end{array}$ & 11.64 & $\begin{array}{r}74 \\
820\end{array}$ & 28.41 & 263340 \\
\hline Vojvodina Region & $\begin{array}{r}1574 \\
366\end{array}$ & 79.39 & $\begin{array}{r}64 \\
643\end{array}$ & 3.6 & $\begin{array}{l}127 \\
551\end{array}$ & 6.43 & $\begin{array}{l}216 \\
594 \\
\end{array}$ & 10.92 & $\begin{array}{r}1983 \\
154 \\
\end{array}$ \\
\hline SERBIA - SOUTH & $\begin{array}{r}1755 \\
995 \\
\end{array}$ & 59.89 & $\begin{array}{l}212 \\
971\end{array}$ & 7.26 & $\begin{array}{l}814 \\
084\end{array}$ & 27.76 & $\begin{array}{l}149 \\
148\end{array}$ & 5.09 & $\begin{array}{r}2932 \\
198 \\
\end{array}$ \\
\hline $\begin{array}{l}\text { Šumadija and Western } \\
\text { Serbia Region }\end{array}$ & $\begin{array}{r}1035 \\
998\end{array}$ & 60.93 & $\begin{array}{r}76 \\
055\end{array}$ & 4.47 & $\begin{array}{l}519 \\
487\end{array}$ & 30.55 & $\begin{array}{r}68 \\
708\end{array}$ & 4.04 & $\begin{array}{r}1700 \\
248 \\
\end{array}$ \\
\hline $\begin{array}{l}\text { Southern and Eastern } \\
\text { Serbia Region }\end{array}$ & 719997 & 58.4 & $\begin{array}{l}136 \\
916 \\
\end{array}$ & 11.11 & $\begin{array}{l}294 \\
597 \\
\end{array}$ & 23.91 & $\begin{array}{r}80 \\
440 \\
\end{array}$ & 6.53 & $\begin{array}{r}1231 \\
950 \\
\end{array}$ \\
\hline $\begin{array}{l}\text { Kosovo and Metohija } \\
\text { Region }\end{array}$ & $\cdots$ & $\ldots$ & $\ldots$ & $\cdots$ & $\cdots$ & $\ldots$ & $\ldots$ & $\ldots$ & $\ldots$ \\
\hline
\end{tabular}

Source: author's calculation based on data of the Statistical Office of the Republic of Serbia

Differences in the representation of the UAA in certain regions range from only $58.44 \%$ in the Region of Southern and Eastern Serbia to $79.39 \%$ in the Region of Vojvodina. Significant differences in the representation of NUAA are evident, ranging between $11.11 \%$ in the Region of Southern and Eastern Serbia to 3.26\% in the Region of Vojvodina. The differences are even greater at the district level. NUAA ranges from $1.17 \%$ (Srem District) to $22.78 \%$ (Pirot District). Thus, the share of UAA by 
regions is between only $58.44 \%$ in the Region of Southern and Eastern Serbia (where landowners left their properties in large numbers) to as many as $79.39 \%$ in the Region of Vojvodina, which is the richest region in Serbia in terms of AL and benefits for agricultural production (Lovre, Zekić, 2008).

There are also significant regional differences in the representation of woodland by districts (Pantić, Živanović Miljković, 2010). Areas covered by woodland comprise $18.77 \%$ of the total AL in the Republic of Serbia. At the level of the defined areas, the share of areas covered by woodland in the total AL ranges from $0.07 \%$ (North Banat District) to $39.58 \%$ (Zlatibor District). However, in relation to the above-mentioned average indicators for Serbia, regional differences in the structure of AL by utilisation categories point to the following statements:

First, the dominant share of the UAA in the total AL is characteristic for all four statistical regions, with the representation of the UAA in Vojvodina Region being significantly above (79.39\%), and in all three regions in central Serbia the representation is relatively uniformed and significantly below the national average and ranges from $55.26 \%$ in the Belgrade region, $60.93 \%$ in the Region of Sumadija and Western Serbia and $58.44 \%$ in the Region of Southern and Eastern Serbia;

Second, the difference between the total AL and UAA indicates a significant representation of one or two of the three individual utilisation categories, namely:

- other land comprises approximately one third of available land in Belgrade region (28.41\%);

- other land is significantly represented in the structure of the AL of the Region of Vojvodina (10.92\%);

- woodland area comprises $30.55 \%$ of AL of Šumadija and Pomoravlje;

- cumulatively shown categories of woodland (23.91\%) and NUAA (23.91\%), comprise about one third of the available land in the Region of Southern and Eastern Serbia (Table 4.)

A significant aspect of the analysis of AL by utilisation categories is also the analysis of the relationship between UAA and NUAA by the legal status of holdings (Lovre, 2013). The majority of AL belongs to FAHs (73.58\%), and 26.42\% to AHLEEs. However, the share of FAHs in utilized area is $83.90 \%$, and AHLEEs only $16.10 \%$. The share of FAHs in NUAA is $35.80 \%$, and AHLEEs even $64.20 \%$. FAHs also has a dominant share in the category of woodland area (72.57\%), and AHLEEs owns only $27.43 \%$ of woodland. 
Table 5. AL by utilization categories and legal status of holdings in the RS, 2018

\begin{tabular}{|c|c|c|c|c|c|c|}
\hline & \multicolumn{5}{|c|}{$\mathbf{A L}$} \\
\hline & & total & UAA & NUAA & Woodland area & Other \\
\hline & & \multicolumn{5}{|c|}{ All agricultural holdings AHs } \\
\hline \multirow{2}{*}{ Area } & ha & 5178692 & 3475894 & 289953 & 972283 & 440562 \\
\hline & $\%$ & 100.00 & 67.12 & 5.60 & 18.77 & 8.51 \\
\hline \multirow{2}{*}{ Holdings } & number & 564542 & 559252 & 109115 & 360662 & 492912 \\
\hline & $\%$ & 100.00 & 99.06 & 19.33 & 63.89 & 87.31 \\
\hline \multirow{2}{*}{ Average } & $\mathrm{ha} / \mathrm{AH}$ & 9.17 & 6.22 & 2.66 & 2.70 & 0.89 \\
\hline & $\%$ & 100.00 & 67.75 & 28.97 & 29.39 & 9.74 \\
\hline & & \multicolumn{5}{|c|}{$\mathrm{AL}$} \\
\hline & & total & UAA & NUAA & Woodland area & Other \\
\hline & & \multicolumn{5}{|c|}{ Family agricultural holdings FAHs } \\
\hline \multirow{2}{*}{ Area } & ha & 3810550 & 2916125 & 103815 & 705567 & 85042 \\
\hline & $\%$ & 100.00 & 76.53 & 2.72 & 18.52 & 2.23 \\
\hline \multirow{2}{*}{ Holdings } & number & 562895 & 557715 & 108727 & 360320 & 492083 \\
\hline & $\%$ & 100.00 & 99.08 & 19.32 & 64.01 & 87.42 \\
\hline \multirow{2}{*}{ Average } & ha/FAH & 6.77 & 5.23 & 0.95 & 1.96 & 0.17 \\
\hline & $\%$ & 100.00 & 77.23 & 14.11 & 28.93 & 2.55 \\
\hline & & \multicolumn{5}{|c|}{ Share FAHs (all AHs $=100$ ) } \\
\hline Area & $\%$ & 73.58 & 83.90 & 35.80 & 72.57 & 19.30 \\
\hline \multirow[t]{2}{*}{ all FAHs } & $\%$ & 99.71 & 99.73 & 99.64 & 99.91 & 99.83 \\
\hline & & \multicolumn{5}{|c|}{ Agricultural holdings of legal entities and entrepreneurs AHLEEs } \\
\hline \multirow{2}{*}{ Area } & ha & 1368142 & 559769 & 186138 & 266716 & 355520 \\
\hline & $\%$ & 100.00 & 40.91 & 13.61 & 19.49 & 25.99 \\
\hline \multirow{2}{*}{ Holdings } & number & 1647 & 1537 & 388 & 342 & 829 \\
\hline & $\%$ & 100.00 & 93.32 & 25.24 & 88.14 & 242.40 \\
\hline \multirow{2}{*}{ Average } & ha/AHLEE & 830.69 & 364.20 & 479.74 & 779.87 & 428.85 \\
\hline & $\%$ & 100.00 & 43.84 & 57.75 & 93.88 & 51.63 \\
\hline & & \multicolumn{5}{|c|}{ Share AHLEEs (all AHs=100) } \\
\hline Area & $(\%)$ & 26.42 & 16.10 & 64.20 & 27.43 & 80.70 \\
\hline $\begin{array}{l}\text { all } \\
\text { AHLEEs }\end{array}$ & $(\%)$ & 0.29 & 0.27 & 0.36 & 0.09 & 0.17 \\
\hline
\end{tabular}

Source: author's calculation based on data of the Statistical Office of the Republic of Serbia

Utilized agricultural area of the total available FAHs land is $76.53 \%$, and unutilized is $2.72 \%$. However, the utilized area of AHLEEs is only $40.91 \%$, and the unutilized area is $13.61 \%$ of the available land of this group of holdings. 
Table 6. Available land by utilization categories and legal status of holdings

\begin{tabular}{|l|c|c|c|}
\hline & All AHs & FAHs & AHLEEs \\
\hline AL & $5178692 \mathrm{ha}$ & $3810550 \mathrm{ha}(73.58 \%)$ & $1368142 \mathrm{ha}(26.42 \%)$ \\
\hline UAA & $3475894 \mathrm{ha}$ & $2916125 \mathrm{ha}(83.90 \%)$ & $559769 \mathrm{ha}(16.10 \%)$ \\
\hline $\mathrm{ha} / \mathrm{AH}$ & $6.22 \mathrm{ha} / \mathrm{AH}$ & $5.23 \mathrm{ha} / \mathrm{FAH}$ & $364.2 \mathrm{ha} / \mathrm{AHLEE}$ \\
\hline $\mathrm{NUAA}$ & $289953 \mathrm{ha}$ & $103815 \mathrm{ha}(35.8 \%)$ & $186138 \mathrm{ha}(64.2 \%)$ \\
\hline $\mathrm{ha} / \mathrm{AH}$ & $2.66 \mathrm{ha} / \mathrm{AH}$ & $0.95 \mathrm{ha} / \mathrm{FAH}$ & $479.7 \mathrm{ha} / \mathrm{AHLEE}$ \\
\hline Woodland & $972 \mathrm{283} \mathrm{ha}$ & $705567 \mathrm{ha}(72.5 \%)$ & $266716 \mathrm{ha}(27.43 \%)$ \\
\hline $\mathrm{ha} / \mathrm{AH}$ & $2.7 \mathrm{ha} / \mathrm{AH}$ & $1.96 \mathrm{ha} / \mathrm{FAH}$ & $779.87 \mathrm{ha} / \mathrm{AHLEE}$ \\
\hline
\end{tabular}

Source: author's calculation based on data of the Statistical Office of the Republic of Serbia

If we take into account the size of AHLEEs property and their large share in the total AL, the following can be concluded:

1. The average size of AH property in Serbia is only $6.22 \mathrm{ha} / \mathrm{AH}$ UAA. The regional analysis of this indicator points out that only holdings in the Region of Vojvodina are with an above-average area of property (12.71 ha/AH or 2.04 times higher) which is the result of the concentration of the largest number by area of significantly larger AHLEEs. In contrast, holdings properties in all three other regions are lower than the national average: $4.89 \mathrm{ha} / \mathrm{AH}$ in the Belgrade region, $4.28 \mathrm{ha} / \mathrm{AH}$ in the Šmadija and Western Serbia Region and 4.40 ha/AH in the Southern and Eastern Serbia Region.

2. Legal entities and entrepreneurs comprise only $0.29 \%$ of the total number of AHs, but they have $26.42 \%$ of the total AHs at their disposal; their share in UAA is $16.10 \%$, and in NUAA $64.20 \%$.

3. AHLEEs are relatively few (1 647), but have a significant average size of property of 364.2 ha of utilised and even 479.74 ha of NUAA and 779.87 ha of woodland.

AHLEEs have at their disposal even 186,138 ha or $64.20 \%$ of the total NUAA in Serbia, which indicates the need for a detailed analysis of the management of agricultural land owned and utilised by this group of entities (Ševarlić, 2015).

\section{Discussions}

The results show that there are significant differences between the three ownership subgroups of all holdings, and they are reflected in the large disproportion of their representation in the total number of holdings and the total area of the UAA. From this point of view, all AHs can be classified into three relatively homogeneous groups of holdings by size of the property - small ("less than 5 ha"), medium ("5-20 ha") and large ("more than 20 ha"). The analysis of the ownership structure according to the share of the defined three collective groups of AHs indicates certain characteristics, as follows:

- AHs with smaller property - is a group in which the dominant part is concentrated, even $71.74 \%$ of the total number of $\mathrm{AH}$ in Serbia, and they utilise only $23.24 \%$ of the total UAA; 
- AHs with medium size of property and comprise $24.29 \%$ of the total number of AHs, and utilise $35.14 \%$ of the total UAA;

- AHs with larger property comprise $3.96 \%$ of the total number of holdings, and utilise $41.62 \%$ of the total UAA.

Regional analysis of the ownership structure of FAHs indicates significant differences in the ownership structure in four statistical regions in Serbia, which are reflected in the following statements:

Table 7. Ownership structure of FAHs in the Republic of Serbia by regions

\begin{tabular}{|c|c|c|c|c|c|c|}
\hline \multicolumn{2}{|c|}{ Indicators } & Total & Without land & $<5$ ha & $5,01-20$ ha & $>20$ ha \\
\hline & & \multicolumn{5}{|c|}{ REPUBLIC OF SERBIA } \\
\hline \multirow{2}{*}{ All FAHs } & number & 562895 & 5180 & 399271 & 136838 & 21606 \\
\hline & $\%$ & 100.00 & 0.92 & 70.93 & 24.31 & 3.84 \\
\hline \multirow{2}{*}{ UAA } & ha & 2916125 & 0 & 806971 & 1218203 & 890951 \\
\hline & $\%$ & 100.00 & 0 & 27.67 & 41.77 & 30.55 \\
\hline & & \multicolumn{5}{|c|}{ Belgrade Region } \\
\hline \multirow{2}{*}{ FAHs } & number & 29949 & 265 & 23069 & 6035 & 580 \\
\hline & $\%$ & 100.00 & 0.88 & 77.03 & 20.15 & 1.94 \\
\hline \multirow{2}{*}{ UAA } & ha & 118872 & 0 & 45131 & 51237 & 22504 \\
\hline & $\%$ & 100.00 & 0.00 & 37.97 & 43.10 & 18.93 \\
\hline & & \multicolumn{5}{|c|}{ Share of the Belgrade Region $(\mathrm{RS}=100)$} \\
\hline All FAHs & $\%$ & 5.32 & 5.12 & 5.78 & 4.41 & 2.68 \\
\hline \multirow[t]{2}{*}{ UAA } & $\%$ & 4.08 & 0.00 & 5.59 & 4.21 & 2.53 \\
\hline & & \multicolumn{5}{|c|}{ Vojvodina Region } \\
\hline \multirow{2}{*}{ FAHs } & number & 126189 & 3128 & 70140 & 37813 & 15106 \\
\hline & $\%$ & 100.00 & 2.48 & 55.58 & 29.97 & 11.97 \\
\hline \multirow{2}{*}{ UAA } & ha & 1168428 & 0 & 122094 & 382918 & 663416 \\
\hline & $\%$ & 100.00 & 0.00 & 10.45 & 32.77 & 56.78 \\
\hline & & \multicolumn{5}{|c|}{ Share of the Vojvodina Region $(\mathrm{RS}=100)$} \\
\hline All FAHs & $\%$ & 22.42 & 60.39 & 17.57 & 27.63 & 69.92 \\
\hline \multirow[t]{2}{*}{ UAA } & $\%$ & 40.07 & 0.00 & 15.13 & 31.43 & 74.46 \\
\hline & & \multicolumn{5}{|c|}{ Šumadija and West Serbia Region } \\
\hline \multirow{2}{*}{ FAHs } & number & 242224 & 740 & 179730 & 58533 & 3221 \\
\hline & $\%$ & 100.00 & 0.31 & 74.20 & 24.16 & 1.33 \\
\hline \multirow{2}{*}{ UAA } & ha & 985301 & 0 & 386710 & 495038 & 103553 \\
\hline & $\%$ & 100.00 & 0.00 & 39.25 & 50.24 & 10.51 \\
\hline & & \multicolumn{5}{|c|}{ Share of the Šumadija and Western Serbia Region $(\mathrm{RS}=100)$} \\
\hline All FAHs & $\%$ & 43.03 & 14.29 & 45.01 & 42.78 & 14.91 \\
\hline \multirow[t]{2}{*}{ UAA } & $\%$ & 33.79 & 0.00 & 47.92 & 40.64 & 11.62 \\
\hline & & \multicolumn{5}{|c|}{ South and East Serbia Region } \\
\hline \multirow{2}{*}{ FAHs } & number & 164533 & 1047 & 126331 & 34456 & 2699 \\
\hline & $\%$ & 100.00 & 0.64 & 76.78 & 20.94 & 1.64 \\
\hline
\end{tabular}




\begin{tabular}{|l|l|r|r|r|r|r|}
\hline \multicolumn{2}{|l|}{ Indicators } & Total & Without land & $<\mathbf{5}$ ha & $\mathbf{5 , 0 1 - 2 0}$ ha & $>\mathbf{2 0}$ ha \\
\hline \multirow{2}{*}{ UAA } & ha & 643525 & 0 & 253035 & 289012 & 101478 \\
\cline { 2 - 7 } & $\%$ & 100.00 & 0.00 & 39.32 & 44.91 & 15.77 \\
\hline & & \multicolumn{7}{|c|}{ Share of the Southern and Eastern Serbia Region $(\mathrm{RS}=100)$} \\
\hline All FAHs & $\%$ & 29.23 & 20.21 & 31.64 & 25.18 & 12.49 \\
\hline UAA & $\%$ & 22.07 & 0.00 & 31.36 & 23.72 & 11.39 \\
\hline \multicolumn{7}{|c|}{ Oosovo and Metohija Region } \\
\hline
\end{tabular}

Source: author's calculation based on data of the Statistical Office of the Republic of Serbia

FAHs larger than 20 ha are dominant in the Region of Vojvodina (69.91\% of the total number of holdings of this size in the Republic of Serbia) and utilize $74.46 \%$ of land in the group of larger properties. Representation of FAHs larger than 20 ha in the Belgrade region is $2.68 \%$, in the region of Šmadija and Western Serbia $14.91 \%$, and in the region of Southern and Eastern Serbia $12.49 \%$ of the holdings of this group.

The largest part of FAHs with a holding of up to 5 ha and FAHs with a holding of medium size (5-20 ha) is in the Region of Šumadija and Western Serbia (over 45\%). In the Region of Southern and Eastern Serbia, FAHs with a property of up to 5 ha (31.64\%) are dominant, and holdings with a property of over 20 ha have almost negligible share in the total number of FAHs.

The general conclusions of the regional analysis of the ownership structure between collective groups of FAHs in Serbia are:

1. small holdings ("up to 5 ha") are dominant in the total number of FAHs in all four statistical regions (between $55.58 \%$ in the Region of Vojvodina and $77.03 \%$ in the Belgrade region), and are in second place in terms of representation in total UAA in all regions (37.97\% in the Belgrade region and 39.32\% in the Region of Southern and Eastern Serbia), while in the region of Šumadija and Western Serbia this group of FAHs utilize $39.25 \%$ of the total UAA of the region, and in the Region of Vojvodina have the lowest share in the UAA $(10.45 \%)$;

2. large holdings ("over 20 ha") are the least represented in the total number of FAHs in all four regions (between $1.33 \%$ in the Region of Šumadija and Western Serbia to $11.97 \%$ in the Region of Vojvodina); they are least represented in the UAA in three regions (between 10.51\% in the region of Šumadija and Western Serbia and 18.93\% in the Belgrade region), while in the region of Vojvodina they are the dominant group in the UAA - they utilize $56.78 \%$ of the UAA region.

3. medium holdings ("5-20 ha") are between small and large holdings in terms of representation in the number of FAHs in all four regions (between $20.15 \%$ in the Belgrade region and $29.97 \%$ in the Vojvodina region); representation in the UAA is $32.77 \%$ in the Region of Vojvodina and $44.91 \%$ in the Region of Southern and Eastern Serbia, and in the Region of Sumadija and Western Serbia they are the most represented, with $50.24 \%$ of the UAA. 
The distribution of AHLEEs and their UAA by regions in Serbia points to the following observation:

Table 8. Ownership structure of AHLEEs in the Republic of Serbia by regions

\begin{tabular}{|c|c|c|c|c|c|c|}
\hline \multicolumn{2}{|l|}{ Indicators } & Total & Without land & $<5$ ha & $5,01-20$ ha & $>20$ ha \\
\hline & & \multicolumn{5}{|c|}{ REPUBLIC OF SERBIA } \\
\hline \multirow{2}{*}{ All AHLEEs } & number & 1647 & 109 & 464 & 300 & 774 \\
\hline & $\%$ & 100.00 & 6.62 & 28.17 & 18.21 & 46.99 \\
\hline \multirow{2}{*}{ UAA } & ha & 559769 & 0 & 834 & 3230 & 555705 \\
\hline & $\%$ & 100.00 & 0 & 0.15 & 0.58 & 99.27 \\
\hline & & \multicolumn{5}{|c|}{ Belgrade Region } \\
\hline \multirow{2}{*}{ AHLEEs } & number & 83 & 6 & 27 & 18 & 32 \\
\hline & $\%$ & 100.00 & 7.23 & 32.53 & 21.69 & 38.55 \\
\hline \multirow{2}{*}{ UAA } & ha & 26661 & 0 & 55 & 198 & 26408 \\
\hline & $\%$ & 100.00 & 0.00 & 0.21 & 0.74 & 99.05 \\
\hline & & \multicolumn{5}{|c|}{ Share of the Belgrade Region $(\mathrm{RS}=100)$} \\
\hline All AHLEEs & $\%$ & 5.04 & 5.50 & 5.82 & 6.00 & 4.13 \\
\hline \multirow[t]{2}{*}{ UAA } & $\%$ & 4.76 & 0.00 & 6.59 & 6.13 & 4.75 \\
\hline & & \multicolumn{5}{|c|}{ Vojvodina Region } \\
\hline \multirow{2}{*}{ AHLEEs } & number & 883 & 45 & 151 & 153 & 534 \\
\hline & $\%$ & 100.00 & 5.10 & 17.10 & 17.33 & 60.48 \\
\hline \multirow{2}{*}{ UAA } & ha & 405938 & 0 & 271 & 1686 & 403981 \\
\hline & $\%$ & 100.00 & 0.00 & 0.07 & 0.42 & 99.52 \\
\hline & & \multicolumn{5}{|c|}{ Share of the Vojvodina Region $(\mathrm{RS}=100)$} \\
\hline All AHLEEs & $\%$ & 53.61 & 41.28 & 32.54 & 51.00 & 68.99 \\
\hline \multirow[t]{2}{*}{ UAA } & $\%$ & 72.52 & 0.00 & 32.49 & 52.20 & 72.70 \\
\hline & & \multicolumn{5}{|c|}{ Šumadija and West Serbia Region } \\
\hline \multirow{2}{*}{ AHLEEs } & number & 412 & 37 & 199 & 85 & 91 \\
\hline & $\%$ & 100.00 & 9.02 & 48.23 & 20.69 & 22.05 \\
\hline \multirow{2}{*}{ UAA } & ha & 50697 & 0 & 355 & 863 & 49479 \\
\hline & $\%$ & 100.00 & 0.00 & 0.70 & 1.70 & 97.60 \\
\hline & & \multicolumn{5}{|c|}{ Share of the Šumadija and Western Serbia Region $(\mathrm{RS}=100)$} \\
\hline All AHLEEs & $\%$ & 25.02 & 33.94 & 42.89 & 28.33 & 11,76 \\
\hline \multirow[t]{2}{*}{ UAA } & $\%$ & 9.06 & 0.00 & 42.57 & 26.72 & 8.90 \\
\hline & & \multicolumn{5}{|c|}{ South and East Serbia Region } \\
\hline \multirow{2}{*}{ AHLEEs } & number & 269 & 21 & 86 & 44 & 118 \\
\hline & $\%$ & 100.00 & 7.95 & 31.82 & 16.22 & 44.01 \\
\hline \multirow{3}{*}{ UAA } & ha & 76472 & 0 & 153 & 482 & 75837 \\
\hline & $\%$ & 100.00 & 0.00 & 0.20 & 0.63 & 99.17 \\
\hline & & \multicolumn{5}{|c|}{ Share of the Southern and Eastern Serbia Region $(\mathrm{RS}=100)$} \\
\hline All AHLEEs & $\%$ & 16.34 & 20.01 & 18.48 & 14.56 & 15.24 \\
\hline \multirow[t]{2}{*}{ UAA } & $\%$ & 13.61 & 0.00 & 18.36 & 14.92 & 13.60 \\
\hline & & \multicolumn{5}{|c|}{ Kosovo and Metohija Region } \\
\hline
\end{tabular}

Source: author's calculation based on data of the Statistical Office of the Republic of Serbia 
Without land is 109 AHLEEs of the total listed AHLEEs $(1,647)$ or $6.62 \%$, which is a significant percentage in relation to the total number of AHs (in the Region of Southern and Eastern Serbia 20.01\%, and in the Region of Šmadija and Western Serbia 33.94\% of the total number of AHLEEs without land). In all regions, AHLEEs with a property of more than 20 ha utilize the largest part of the land available to this group of holdings. The analysis of the ownership structure of the AHLEEs in four statistical regions in Serbia, according to the representation of three collective groups of holdings with a certain size of property, indicates the following regional differences:

Small holdings dominate in the total number of holdings, and are minor in the total UAA holdings of legal entities and entrepreneurs in three regions - Belgrade $32.53 \%$ of AHLEEs of this region and $0.21 \%$ of UAA of AHLEEs), in the Region of Šmadija and Western Serbia (48.23\% of AHLEEs of this region and $0.70 \%$ of UAA of AHLEEs of the region) and Southern and Eastern Serbia (31.82\% of AHLEEs and $0.20 \%$ of UAA of AHLEEs), while in the Region of Vojvodina the representation is in the number of holdings (17.10\% of AHLEEs), and the least represented are in UAA $(0.07 \%$ of UAA of AHLEEs of this region );

Large holdings dominate in the total of UAA and are differently represented in the total number of AHLEEs in all four statistical regions - in the Belgrade region this group makes $38.55 \%$ of AHLEEs region and $99.05 \%$ of UAA of AHLEE of this region, in Vojvodina this group is $60.48 \%$ of AHLEEs and $99.52 \%$ of UAA of AHLEEs region, in Sumadija and Western Serbia they comprise $22.05 \%$ of AHLEEs and $97.60 \%$ of UAA of AHLEEs, and in Southern and Eastern Serbia 44.01\% of AHLEEs and 99.17\% of UAA of AHLEEs of this region;

Medium holdings are relatively more represented in the total number, and minor in the total of UAA of AHLEEs in all four statistical regions - in the Belgrade region this group of holdings comprises $21.69 \%$ of AHLEEs and utilizes $0.74 \%$ of UAA of AHLEEs of this region; in the Region of Vojvodina $17.33 \%$ are AHLEEs and utilize $0.42 \%$ of UAA of AHLEEs of this region; in the region of Sumadija and Western Serbia $20.69 \%$ of AHLEEs is this group of holdings and they utilize $1.70 \%$ of UAA of AHLEEs of this region, in the Region of Southern and Eastern Serbia this group comprises $16.22 \%$ of AHLEEs and utilizes $0.63 \%$ of UAA of AHLEEs of this region.

FAHs are dominant in the total number of holdings $(99.71 \%)$ and, at a slightly lower level, in the total number of UAA $(83.84 \%)$.

FAHs with smaller property are dominant in the total number of FAHs in all four statistical regions $-70.95 \%$ of the total number of FAHs, and their share in the UAA is only $27.67 \%$. This result suggests a large fragmentation of FAHs properties.

FAHs with a medium size of property comprise $24.31 \%$ of the total number of FAHs, and the share in UAA is $41.77 \%$. The largest part of FAHs with medium-sized property is in the Region of Šumadija and Western Serbia (over 45\%).

FAHs with larger property comprise only $3.84 \%$ of FAHs, and their share in UAA is $30.57 \%$. So the number of large FAHs is small, but they utilize one third of the FAHs land. 
Large holdings are the least represented in the total number of FAHs in all four regions; in the Region of Vojvodina and the dominant group in the UAA, utilize $56.78 \%$ of the UAA region.

Table 9. Regional analysis of the ownership structure of FAHs collective groups in Serbia

\begin{tabular}{|l|r|r|l|r|r|r|}
\hline \multirow{2}{*}{ Region } & \multicolumn{2}{|l|}{ Small holdings up to 5 ha } & \multicolumn{2}{l|}{ Medium holdings 5-20 ha } & \multicolumn{2}{|l|}{$\begin{array}{l}\text { Large holdings over } \\
20 \text { ha }\end{array}$} \\
\cline { 2 - 8 } & $\begin{array}{l}\text { Share } \\
\text { in the } \\
\text { number of } \\
\text { FAH }\end{array}$ & $\begin{array}{l}\text { Share in } \\
\text { UAA }\end{array}$ & $\begin{array}{l}\text { Share } \\
\text { in the } \\
\text { number of } \\
\text { FAH }\end{array}$ & $\begin{array}{l}\text { Share in } \\
\text { UAA }\end{array}$ & $\begin{array}{l}\text { Share } \\
\text { in the } \\
\text { number of } \\
\text { FAH }\end{array}$ & $\begin{array}{l}\text { Share in } \\
\text { UAA }\end{array}$ \\
\hline Belgrade Region & $77.03 \%$ & $37.97 \%$ & $20.15 \%$ & $43.10 \%$ & $1.94 \%$ & $18.93 \%$ \\
\hline Vojvodina Region & $\mathbf{5 5 . 5 8 \%}$ & $\mathbf{1 0 . 4 5 \%}$ & $29.97 \%$ & $32.77 \%$ & $\mathbf{1 1 . 9 7 \%}$ & $\mathbf{5 6 . 7 8 \%}$ \\
\hline $\begin{array}{l}\text { Sumadija and West } \\
\text { Serbia Region }\end{array}$ & $74.20 \%$ & $39.26 \%$ & $24.16 \%$ & $50.24 \%$ & $1.33 \%$ & $10.51 \%$ \\
\hline $\begin{array}{l}\text { South and East } \\
\text { Serbia Region }\end{array}$ & $76.78 \%$ & $39.32 \%$ & $20.94 \%$ & $44.91 \%$ & $1.64 \%$ & $15.77 \%$ \\
\hline Kosovo Region & & & & & & \\
\hline
\end{tabular}

Source: author's calculation based on data of the Statistical Office of the Republic of Serbia

AHLEEs represent, by number, a small group (only 1,647 households or $0.29 \%$ of the total number of AHs), but have a significantly higher share in UAA (16.10\%)

AHLEEs with smaller property comprise $28.71 \%$ of the total number of holdings in this group, and their share in UAA is only $0.15 \%$ (excluding land $6.67 \%$ ). These holdings dominate in the number of AHLEEs, and are minor in the total UAA of AHLEEs holdings in three regions; AHLEEs with a medium size of holdings comprise $18.21 \%$, and their share in the UAA is only $0.58 \%$. AHLEEs with larger holdings comprise $47 \%$, and their share in the UAA is even $99 \%$. However, in the category of holdings larger than 100 ha it is $29.57 \%$ of the total number of AHLEEs and they utilize $96.76 \%$ of the land of this group of holdings. Large holdings dominate in the total of UAA and are differently represented in the total number of AHLEEs in regions.

Table 10. Regional analysis of the ownership structure of AHLEEs in Serbia, 2018

\begin{tabular}{|l|r|r|r|r|r|r|}
\hline \multirow{2}{*}{ Region } & \multicolumn{2}{|c|}{ Small holdings up to 5 ha } & \multicolumn{2}{|c|}{$\begin{array}{l}\text { Medium holdings 5-20 } \\
\text { ha }\end{array}$} & \multicolumn{2}{c|}{ Large holdings over 20 ha } \\
\cline { 2 - 7 } & $\begin{array}{l}\text { Share in the } \\
\text { number of } \\
\text { AHLEEs }\end{array}$ & $\begin{array}{l}\text { Share in } \\
\text { UAA }\end{array}$ & $\begin{array}{l}\text { Share in } \\
\text { the number } \\
\text { of AHLEEs }\end{array}$ & $\begin{array}{l}\text { Share in } \\
\text { UAA }\end{array}$ & $\begin{array}{l}\text { Share in the } \\
\text { number of } \\
\text { AHLEEs }\end{array}$ & $\begin{array}{l}\text { Share in } \\
\text { UAA }\end{array}$ \\
\hline $\begin{array}{l}\text { Belgrade } \\
\text { Region }\end{array}$ & $32.53 \%$ & $0.21 \%$ & $21.69 \%$ & $0.74 \%$ & $38.55 \%$ & $99.05 \%$ \\
\hline $\begin{array}{l}\text { Vojvodina } \\
\text { Region }\end{array}$ & $17.10 \%$ & $0.07 \%$ & $17.33 \%$ & $0.42 \%$ & $60.48 \%$ & $99.50 \%$ \\
\hline $\begin{array}{l}\text { Sumadija and } \\
\text { West Serbia } \\
\text { Region }\end{array}$ & $48.23 \%$ & $0.70 \%$ & $20.69 \%$ & $1.70 \%$ & $22.05 \%$ & $97.60 \%$ \\
\hline $\begin{array}{l}\text { South and East } \\
\text { Serbia Region }\end{array}$ & $31.82 \%$ & $0.20 \%$ & $16.22 \%$ & $0.63 \%$ & $44.00 \%$ & $99.17 \%$ \\
\hline Kosovo Region & & & & & & \\
\hline
\end{tabular}

Source: author's calculation based on data of the Statistical Office of the Republic of Serbia 
The analysis of the ownership structure of all AHs according to the legal status of holdings in Serbia indicates that:

FAHs is dominant in the total number of holdings (99.71\%) and, at a slightly lower level, in the total UAA (83.84\%). In the group of holdings with smaller property, FAHs occupy $70.95 \%$ of the total number of FAHs, and their share in UAA is only $27.67 \%$. This result suggests a large fragmentation of FAHs properties. In the group of holdings with medium size of property, there are $24.31 \%$ of the total number of FAHs, and their share in the UAA of FAHs is $41.77 \%$. In the group of holdings with larger property, only $3.84 \%$ are FAHs, and their share in the UAA of this group of holdings is $30.57 \%$. So the number of large FAHs is small, but they utlize one third of the FAHs land;

AHLEEs by number represent a small group of holdings (only 1,647 households or $0.29 \%$ of the total number of AHs), but have a significantly higher share in the total UAA (16.10\%) and are the dominant category by number of holdings and UAA in two groups of holdings with larger properties (over 20 ha and over 100 ha). In the group of holdings with smaller properties, AHLEEs comprise $0.12 \%$ of the total number of holdings in this group, and their share in UAA is only $0.11 \%$. In the group of holdings with medium-sized property, AHLEEs comprise $0.22 \%$, and their share in UAA in this group is only $0.26 \%$. In the group of holdings with larger property, AHLEEs comprise $3.58 \%$, and their share in UAA is as high as $38.41 \%$. However, in the category of properties larger than 100 ha there is $29.57 \%$ of the total number of AHLEEs and they utilize $96.76 \%$ of the land of this group of holdings.

AHLEEs are relatively small $(1,647)$, but have a significant average size of property, an average of 364 ha of utilized property and even 479 ha of NUAA; 779 ha of woodland. AHLEEs have at their disposal even 186,138 ha or $64.20 \%$ of the total NUAA in Serbia, which indicates the need for a detailed analysis of agricultural land management in this group of entities.

\section{Conclusions}

The aim of this paper represents a realistic view of economic strength and type of agricultural production on holdings in Serbia, in order to obtain a quality, analytical and comparable basis for analysis of structural characteristics and economic parameters of AHs and conceptualization of agricultural policy measures, but also for comparative analysis with AHs in EU countries and neighboring countries [Simonović, 2004], as well as a base for scientists in further scientific research on the structural characteristics and economic performance of agricultural holdings in Serbia. Systematization of data and analysis of the obtained results led to a number of important conclusions about this segment of agriculture in the Republic of Serbia. Some of the basic conclusions can be singled out in a brief review of the overall results obtained.

According to the obtained results in the Republic of Serbia in 2018, there are 564,542 agricultural holdings, 562,895 family agricultural holdings, 1,375 agricultural holdings of legal entities and 272 agricultural holdings of entrepreneurs. It can be concluded that 
the total number of holdings is dominated by family holdings $(99.71 \%)$. The largest part of the total number of FAHs is in the region of Sumadija and Western Serbia (about $43 \%$ ), and the smallest is in the region of Vojvodina $(5.32 \%)$. AHLEEs are minor in number (only $0.29 \%$ ), but this group has a significant share in the UAA and a large average area of property, so it can be concluded that they are important production and economic entities in Serbian agriculture.

It can be concluded that Serbian agriculture is characterized by a dominant number of FAHs in relation to the AHLEEs. The average size of property is small (6.22 ha/ AH; 5.23 ha/FAH and 364.2 ha/AHLEE - Table 6). The FAHs category is dominated by FAHs with a property of less than 5 ha, and in the AHLEEs category the most represented are entities with a property of more than 20 ha. This ownership group uses the largest part of the land in all observed regions. There is an obvious contrast between the smallest and the largest ownership group of holdings and their representation in the total number of agricultural holdings AHs and in the total area UAA.

\section{Acknowledgements}

In this research, data collected by the "Agricultural farms structure survey in Serbia, 2018" were used. The organization and implementation of the Survey was financed from the budget of the Republic of Serbia and from the pre-accession funds of the European Union, within the IPA 2016 project (Instrument for Pre-accession Assistance, 2016). The author is employed at the University of Novi Sad, Faculty of Economics in Subotica, Serbia.

\section{Conflict of Interest}

The authors declare that they have no conflict of interest.

\section{References}

1. Bogdanov, N. (2007). Small Rural Households in Serbia and Rural NonAgricultural Economy. Beograd: UNDP. [in Serbian: Bogdanov, N. (2007). Mala ruralna domaćinstva u Srbiji i ruralna nepoljoprivredna ekonomija]

2. https://www.researchgate.net/publication/323346109_Mala_ruralna_ domacinstva_u_Srbiji_i_ruralna_nepoljoprivredna_ekonomija

3. Đorđević, A., Knežević, M., Tomić, Z, Golubović, S., Onjija, A., Životić, Lj. \& Nikolić, N. (2011). Methodology for Systematic Monitoring of Land Quality and Condition in the Republic of Serbia. Beograd: Univerzitet $u$ Beogradu - Poljoprivredni fakultet [in Serbian: Metodologija za sistematsko praćenje kvaliteta i stanja zemljišta u Republici Srbiji] https:/www.google.com/url?sa= $\mathrm{t} \& \mathrm{rct}=\mathrm{j} \& \mathrm{q}=\&$ esrc $=\mathrm{s} \&$ source $=$ web $\& \mathrm{~cd}=\& \mathrm{ved}=2 \mathrm{ahUKEwif6pvDyu3qAhXmQ}$ UEAHUviB-QQFjABegQIAxAB\&url=https\%3A\%2F\%2Fwww.ekologija.gov. rs\%2F\%3Fwpfb_dl\%3D47\&usg=AOvVaw1nBkKRbO8rS8CVQ6JZ6HR3 
4. European Commission. (2012). Agriculture in the European Union. Statistical and Economic Information 2011, EU Directorate - General for Agriculture and Rural Development, Brussels https:/www.google.com/url?sa=t\&rct=j\&q=\&e $\mathrm{src}=\mathrm{s} \&$ source $=$ web $\& \mathrm{~cd}=\& \mathrm{ved}=2 \mathrm{ahUKEwjE} 1 \mathrm{sPJy}-3 \mathrm{qAhWMY} 8 \mathrm{AKHX}-\mathrm{aA} 9$ 0QFjABegQIAxAB\&url=https $\% 3 \mathrm{~A} \% 2 \mathrm{~F} \% 2 \mathrm{Feur}-\mathrm{lex}$.europa.eu $\% 2$ Fresource. html\%3Furi\%3Dcellar\%3A58d03bba-ca5d-42cb-aba6-8ce38f10898f.0001.02\%2 FDOC_1\%26format $\% 3 D P D F \& u s g=A$

5. Lovre, K. \& Zekić, S. (2008). Contradiction and Complementarity of Agrarian Policy and Rural Development Policy. Anali, Ekonomskog fakulteta u Subotici, Br. 20: 91-97. ISSN 0350-2120 [in Serbian: Lovre, K., Zekić, S. (2008). Protivrečnost i komplementarnost agrarne politike i politike ruralnog razvoja] http://scindeks. ceon.rs/article.aspx?artid=0350-21200820091L

6. Lovre, K. (2013). Policy Of Support To Agriculture And Rural Development. AgriFood Sector in Serbia: State and Challenges. Serbian Association of Agricultural Economists, number 157558 edited by Škorić, D., Tomić, D. \& Popović, V. https:// ideas.repec.org/b/ags/saaemn/157558.html

7. Pantić, M. \& Živanović Miljković, J. (2010). Regional Diferencies between Rural Areas of Serbia in Population Aging and Agricultural Activities: Case Studies of the Inđija and Knjaževac Municipalities. SPATIUM International Review, 22, 2937. http://raumplan.iaus.ac.rs/handle/123456789/179

8. Petrović, Ž., Miladinović, M. \& Novakov, M. (2007). Development of Local Advisory Service and Employment of Agricultural Experts. Economics of Agriculture, 54(1): 25-39. [in Serbian: Petrović, Ž., Miladinović, M., Novakov, M. (2007). Razvoj lokalne savetodavne službe i zapošljavanje poljoprivrednih stručnjaka] http://scindeks.ceon.rs/article.aspx?artid=0352-34620701025P

9. Simonović, Z. (2004). Land ownership problems in transition. Economics of Agriculture, 51(3-4): 17-23. [in Serbian: Simonović, Z. (2004). Problemi zemljišne svojine u tranziciji] https://scindeks.ceon.rs/article.aspx?query=ISSID $\% 26$ and $\% 2$ 63715 \&page $=1 \&$ sort $=8$ \&stype $=0$ \&backurl $=\% 2$ Fissue. aspx $\% 3$ Fissue $\% 3$ D 3715

10. Ševarlić, M. (2015). Agricultural Land in the Republic of Serbia. Beograd: Republički zavod za statistiku. [in Serbian: Ševarlić, M. (2015). Poljoprivredno Zemljište u Republici Srbiji] https://issuu.com/zavodstatistika/docs/ poljoprivredno_zemljiste_-_web

11. Todić, B. (2019). Fruit growing. Beograd: Republički zavod za statistiku. [in Serbian: Todić, B. (2019). Voćarstvo.] https://www.stat.gov.rs/sr-latn/oblasti/ poljoprivreda-sumarstvo-i-ribarstvo/anketaostrukturipopgazdinstava/

12. Tomić, D. \& Njegovan, Z. (2013). Agriculture of the Western Balkan Countries in Globalisation and Liberalisation Processes. Serbian Association of Agricultural Economics. https://ideas.repec.org/b/ags/saaemn/157565.html

13. Trivić, N. (2019). Land. Beograd: Republički zavod za statistiku. [in Serbian: Trivić, N. (2019). Zemljište.] https://www.stat.gov.rs/sr-latn/oblasti/poljoprivredasumarstvo-i-ribarstvo/anketaostrukturipopgazdinstava/ 
